\title{
KRITERIA FISABILILLAH DI LEMBAGA PENGELOLA ZAKAT INDONESIA
}

\section{FISABILILLAH CRITERIA AT INDONESIAN ZAKAT MANAGEMENT AGENCY}

\author{
F.N. Ummah'1a; T. Kurnia² \\ 1aProgram Studi Ekonomi Syariah Fakultas Ekonomi Islam Universitas Djuanda Bogor, \\ Jl. Tol Ciawi No 1 Kotak Pos 35 Ciawi Bogor 16720, \\ e-mail: fienanafirulu@gmail.com \\ 2Program Studi Ekonomi Syariah Fakultas Ekonomi Islam Universitas Djuanda Bogor, Jl. \\ Tol Ciawi No 1 Kotak Pos 35 Ciawi Bogor 16720, \\ e-mail: tuti.kurnia@unida.ac.id
}

\begin{abstract}
ABSTRAK
Penelitian ini bertujuan untuk menganalisis kriteria fisabilillah di lembaga pengelola zakat Indonesia. Penelitian ini dilatarbelakangi oleh penyaluran dana zakat yang dilakukan oleh lembaga pengelola zakat di Indonesia yang lebih banyak dialokasikan untuk beberapa golongan. Oleh sebab itu, diperlukan analisis tentang kriteria fisabilillah dan kesesuaian kriteria fisabilillah di Indonesia. Jenis penelitian ini adalah penelitian deskriptif kualitatif dengan menggunakan analytic hierarki prosses (AHP). Teknik pengambilan sampel menggunakan metode purposive sampling. Hasil penelitian mendapati bahwa tiga lembaga pengelola zakat, dana zakat yang didistribusikan kepada golongan fisabilillah adalah untuk para dai yang menyebarkan Islam, untuk beasiswa bagi para pelajar, dan untuk kemaslahatan umum umat muslim. Kriteria kesesuaian mustahik golongan fisabilillah sudah sesuai dengan kriteria menurut syariat Islam.
\end{abstract}

Kata Kunci: Kriteria Fisabilillah, Zakat, LPZ

\begin{abstract}
The study aimed to analyze the criteria fisabilillah in zakat management institutions Indonesia. This research is based on the distribution of zakat funds conducted by zakat management institutions in Indonesia which are allocated more for several groups. Therefore, an analysis of fisabilillah criteria and conformity of fisabilillah criteria in Indonesia is needed. The type of this research is qualitative descriptive research using analytic hierarchy of prosses (AHP). The sampling technique used purposive sampling method. The result in this study that three zakat management institutions, zakat funds distributed to fisabilillah groups are for the dai who spread Islam, for scholarships for students, and for the common good of Muslims. The criteria of conformity mustahikfisabilillah groups are in accordance with the criteria according to Islamic Shari'a.
\end{abstract}


Keywords: Fisabilillah Criterion, Zakat, LPZ

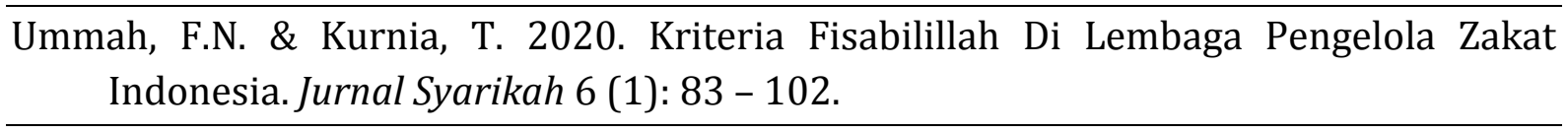

\section{PENDAHULUAN}

Zakat merupakan suatu ibadah yang memiliki dua dimensi yaitu dimensi $h a b l$ min Allah (hubungan vertikal) dan dimensi habl min an-nas (hubungan horizontal). Buah dari ibadah zakat yang berdimensi vertikal, dapat membentuk karakter-karakter yang baik bagi seorang muslim yang berzakat (muzakki) maupun yang menerima (mustahik). Diantaranya membersihkan diri dari sifat bakhil, menghilangkan sifat kikir para pemilik harta, mengembangkan rasa tanggung jawab sosial, terutama bagi pemilik harta, menentramkan perasaan mustahik, melatih atau mendidik berinfak dan memberi, menumbuhkan kekayaan hati dan mensucikan diri dari dosa, mensucikan harta para muzakki dan lainlain.

Hubungan horizontal memiliki tujuan yaitu untuk menyantuni dan mengentaskan kemiskinan, membantu masyarakat muslim yang sedang kesulitan maupun membantu memberikan materi untuk orang yang berjuang di jalan Allah dengan baik dan benar.

Imam Syafii, Hambali dan Maliki mereka sepakat bahwa untuk golongan fakir dan miskin adalah orang-orang yang berada dalam keadaan kurang mampu untuk memenuhi kebutuhan pokoknya. Baik untuk kebutuhan pangan, sandang dan papan (Qardawi, 2011: 513). Untuk golongan amil, zakat diberikan bagi orang-orang yang mengelola zakat baik dalam penghimpunan, pengelolaan dan pendistribusian zakat dari muzakki kepada mustahik (Al-Utsaimin, 2012: 332).

Untuk golongan muallaf, zakat diberikan untuk orang yang baru masuk Islam dan hati mereka masih lemah sehingga mudah untuk digoyahkan dan kembali kepada agamanya terdahulu. Dengan pemberian zakat ini dimaksudkan agar hati mereka menjadi teguh dalam menganut agama Islam. Untuk golongan riqab, zakat diberikan untuk membebaskan budak-budak. Pada zaman sekarang perbudakan sudah tidak ada lagi, oleh karena itu zakat untuk golongan ini diberikan untuk membebaskan tawanan-tawanan perang. Untuk golongan gharim, zakat diberikan kepada orang-orang yang sedang mengalami kesulitan dalam pembayaran hutang dan hutang tersebut bukan untuk maksiat.

Fisabilillah adalah kalimat yang bersifat umum mencakup segala amal perbuatan ikhlas, yang dipergunakan untuk mendekatkan diri kepada Allah dengan melaksanakan segala perbuatan wajib, sunat, dan berbagai macam kebaikan lainnya (Qardawi, 2011: 610). Makna perluasan fisabilillah adalah orang yang berjuang dijalan Allah seperti orang yang berjuang di medan perang dan orang yang berjuang untuk membela serta menegakkan kalimatullah, 
seperti ustadz yang mengajarkan agama Islam, pelajar/santri jika waktunya dihabiskan untuk belajar ilmu agama Islam, untuk persiapan perang (membeli senjata, membangun benteng) dan membangun madrasah Islam untuk memperkuat agama Islam.

Adapun laporan keuangan lembaga pengelola zakat Indonesia dalam menyalurkan dana zakat kepada mustahik adalah sebagai berikut:

Tabel 1. Laporan Keuangan Lembaga Pengelola Zakat

\begin{tabular}{|l|l|l|l|}
\hline $\begin{array}{l}\text { Penyalur } \\
\text { an Zakat }\end{array}$ & $\begin{array}{l}\text { DPU- } \\
\text { DT } \\
\mathbf{2 0 1 3}\end{array}$ & $\begin{array}{l}\text { Dompet } \\
\text { Dhuafa } \\
\mathbf{2 0 1 3}\end{array}$ & $\begin{array}{l}\text { Rumah } \\
\text { Zakat } \\
\mathbf{2 0 1 3}\end{array}$ \\
\hline $\begin{array}{l}\text { Fakir } \\
\text { Miskin }\end{array}$ & $\begin{array}{l}2,940, \\
952,29 \\
5\end{array}$ & $\begin{array}{l}60,492,5 \\
88,778\end{array}$ & $\begin{array}{l}2,091,477 \\
, 498\end{array}$ \\
\hline Amil & $\begin{array}{l}474,07 \\
9,373\end{array}$ & $\begin{array}{l}15,466,0 \\
37,317\end{array}$ & $\begin{array}{l}9,767,596 \\
, 80\end{array}$ \\
\hline Riqob & 0 & 0 & 0 \\
\hline Gharimin & $\begin{array}{l}500,00 \\
0\end{array}$ & $\begin{array}{l}771,346, \\
000\end{array}$ & 0 \\
\hline Muallaf & $\begin{array}{l}1,460, \\
000\end{array}$ & $\begin{array}{l}24,020,4 \\
95\end{array}$ & 0 \\
\hline Sabilillah & $\begin{array}{l}\mathbf{3 5 0 , 3 4} \\
\mathbf{7 , 4 3 9}\end{array}$ & $\begin{array}{l}\mathbf{3 2 , 9 4 1}, \\
\mathbf{4 2 0 , 9 9 9}\end{array}$ & $\mathbf{7 2 8 , 3 7 8 ,}$ \\
\hline Ibnu Sabil & $\begin{array}{l}8,896, \\
000\end{array}$ & $\begin{array}{l}135,294, \\
922\end{array}$ & 0 \\
\hline $\begin{array}{l}\text { Jumlah } \\
\text { Penyalur } \\
\text { an }\end{array}$ & $\begin{array}{l}\mathbf{3 , 7 7 6} \\
\mathbf{2 3 5 , 1} \\
\mathbf{0 7}\end{array}$ & $\begin{array}{l}\mathbf{1 0 9 , 8 3 0} \\
\mathbf{7 0 8 , 5 1} \\
\mathbf{1}\end{array}$ & $\mathbf{1 2 , 5 8 7 , 4}$ \\
\hline
\end{tabular}

Sumber: Laporan Keuangan Zakat Tahun 2013

Dari data di atas terlihat bahwa penyaluran dana zakat yang dilakukan oleh lembaga pengelola zakat Indonesia lebih banyak dialokasikan untuk golongan fakir, miskin, amil dan fisabilillah. Padahal makna dari golongan fisabilillah itu sendiri masih menjadi perdebatan para ulama dalam menentukan perluasan maknanya.
Banyaknya perluasan makna dari golongan fisabilillah dan banyaknya dana zakat yang dialokasikan untuk golongan fisabilillah, maka penulis ingin mengetahui tentang kriteria fisabilillah sebagai mustahik zakat di lembaga pengelola zakat Indonesia.

\section{MATERI DAN METODE}

\section{Konsep Zakat}

Zakat menurut bahasa adalah suci, bersih, baik, berkembang, tumbuh, berkah dan bertambah (Qardawi, 2011: 34). Yusuf Qardawi mendefinisikan zakat adalah sejumlah harta tertentu yang diwajibkan Allah menyerahkannya kepada orang-orang yang berhak. Zakat juga bisa diartikan mengeluarkan jumlah harta tertentu itu sendiri. Artinya, perbuatan mengeluarkan hak yang wajib dari harta pun dinamakan zakat dan bagian tertentu yang dikeluarkan dari harta itu pun dinamakan zakat (Dahlan, 2001 : 1985).

Sedangkan menurut istilah fikih adalah sejumlah harta tertentu yang diwajibkan Allah untuk diserahkan kepada orang-orang yang berhak menerima zakat (mustahik) dari orang yang wajib mengeluarkan zakat (muzakki) setelah memenuhi haul dan nisab. Menurut Ibnu Taimiyah yang dikutip oleh Yusuf Qardawi, jiwa orang yang berzakat itu menjadi bersih dan kekayaannya akan bersih pula. Maksudnya bersih dan bertambah (Qardawi, 2011 : 35).

Dalam istilah ekonomi, zakat merupakan suatu kegiatan pemindahan harta kekayaan dari golongan yang mampu kepada golongan yang tidak mampu. Transfer kekayaan berarti juga 
transfer sumber-sumber ekonomi. Menurut Rahardjo bahwa dengan menggunakan pendekatan ekonomi, zakat bisa berkembang menjadi konsep kemasyarakatan (muamalah), yaitu konsep tentang bagaimana cara manusia melakukan kehidupan bermasyarakat termasuk didalamnya bentuk ekonomi. Oleh karena itu, ada dua konsep yang selalu dikemukakan dalam pembahasan mengenai sosial ekonomi Islam yang saling berkaitan yaitu pelarangan riba dan perintah membayar zakat.

Sedangkan pengertian zakat dalam UU Nomor 23 Tahun 2011, menyebutkan bahwa zakat adalah harta yang wajib dikeluarkan oleh seorang muslim atau badan usaha untuk diberikan kepada yang berhak menerimanya sesuai dengan syariat Islam.

Ulama fikih menetapkan bahwa hikmah zakat adalah sebagai berikut sesuai dengan Al-Qur'an dan Hadits (Dahlan, 2001 : 1986):

1. Memelihara harta orang-orang kaya dari tangan-tangan penjahat yang disebabkan karena terjadinya kesenjangan sosial.

2. Membantu para fakir miskin dan orang-orang yang membutuhkan, sehingga kecemburuan sosial dapat dihilangkan serta ketentraman dan kestabilan masyarakat dan negara terjamin.

3. Membersihkan diri dari sifat kikir dan pelit, sehingga orang kaya meyakini secara sadar bahwa zakat adalah bukan hanya kewajiban semata melainkan tanda rasa solidaritas sosial yang diwajibkan oleh Allah SWT.

4. Membersihkan harta yang diperoleh yang mungkin dalam perolehannya terjadi kekhilafan dan kealpaan yang tidak disengaja.

5. Menunjukkan rasa syukur atas nikmat kekayaan yang telah diberikan oleh Allah SWT.

\section{Distribusi Zakat}

Menurut Anas Zarqa, definisi distribusi itu sebagai suatu transfer dari pendapatan kekayaan antara individu dengan cara pertukaran (melalui pasar) atau dengan cara lain, seperti warisan, shadaqah, wakaf dan zakat. Jadi konsep distribusi menurut pandangan Islam ialah peningkatan dan pembagian bagi hasil kekayaan agar sirkulasi kekayaan dapat ditingkatkan, sehingga kekayaan yang ada dapat melimpah dengan merata dan tidak hanya beredar di antara golongan tertentu saja serta dapat member kontribusi kearah kehidupan manusia yang baik. Adapun distribusi diaplikasikan dalam bentuk pungutan pajak (baik pajak yang bersifat individu maupun pajak perusahaan). Akan tetapi masyarakat juga dapat melaksanakan swadaya melalui pelembagaan ZIS, di mana dalam hal ini pemerintah tidak terlibat langsung dalam mobilisasi pengelolaan pendapatan ZIS yang diterima (An-Nabhani, 1996).

Distribusi zakat adalah kegiatan suatu badan atau organisasi dalam menyalurkan dana zakat yang telah diterima dari muzakki kepada mustahik sehingga tercapai tujuan organisasi secara efektif.

Menurut Yusuf Qardawi ada beberapa cara untuk mendistribusikan dana zakat secara professional, yaitu (Mukhlisin,2009):

1. Pola Pendistribusian Produktif

Pola pendistribusian produktif adalah pola penyaluran dana zakat 
kepada mustahik dengan cara meminjamkan dana zakat oleh amil untuk kepentingan aktifitas suatu usaha/bisnis mustahik.

\section{Pendistribusian Secara Lokal}

Pendistribusian secara lokal adalah bahwa para mustahik di masing-masing wilayah lebih diprioritaskan daripada wilayah lain, sebagaimana dikenal dengan konsep otonomi daerah

3. Pendistribusian Yang Adil Terhadap Semua Golongan

Pendistribusian yang adil terhadap semua golongan adalah adil terhadap semua golongan yang telah dijanjikan oleh Allah dan Rasul-Nya dan adil diantara semua individu dalam satu golongan mustahik.

\section{Mustahik Zakat}

Mustahik zakat ialah yang berhak menerima zakat. Adapun penjelasan mustahik zakat sebagai berikut:

1. Fakir

Fakir adalah orang yang penghasilannya tidak dapat memenuhi kebutuhan pokok (primer) sesuai dengan kebiasaan masyarakat dan wilayah tertentu. Menurut pandangan mayoritas ulama fikih, fakir adalah orang yang tidak memiliki harta dan penghasilan yang halal, atau yang mempunyai harta yang kurang dari nisab zakat dan kondisinya lebih buruk dari pada orang miskin.

Menurut mazhab Hanafi, fakir adalah orang yang tidak memiliki apa-apa dibawah nilai nisab menurut hukum zakat yang sah, atau nilai sesuatu yang dimiliki mencapai nisab atau lebih, yang terdiri dari perabot rumah tangga, barang-barang, pakaian, buku-buku sebagai keperluan pokok sehari-hari. Tetapi para ulama Mazhab Hanafi dalam Hamisy yang dikutip oleh Yusuf Qardawi masih berbeda pendapat tentang batasan nisab yang ditentukan untuk mengukur fakir atau tidak. Yakni apakah nisab uang tunai sebanyak dua ratus dirham atau nisab yang sudah dikenal dari harta apapun juga (Qardawi, 2011 : 513). Sedangkan menurut ketiga Imam, fakir adalah mereka yang tidak mempunyai harta atau penghasilan layak dalam memenuhi keperluannya, baik sandang, pangan, tempat tinggal dan segala keperluan pokok lainnya, baik untuk diri sendiri ataupun bagi mereka yang menjadi tanggungannya.

2. Miskin

Miskin adalah orang-orang yang memerlukan, yang tidak dapat menutupi kebutuhan pokoknya sesuai dengan kebiasaan yang berlaku. Miskin menurut mayoritas ulama adalah orang yang tidak memiliki harta dan tidak mempunyai pencarian yang layak untuk memenuhi kebutuhannya.

Menurut Mazhab Hanafi, miskin adalah mereka yang tidak memiliki apaapa. Sedangkan menurut ketiga Imam lainnya, miskin adalah orang yang mempunyai harta atau penghasilan layak dalam memenuhi keperluannya dan orang yang menjadi tanggungannya, tetapi tidak sepenuhnya tercukupi.

Menurut Syamsussin Ramli dalam Yusuf Qardawi, para ulama memberikan batasan, bahwa miskin adalah mereka yang dapat memenuhi separuh kebutuhan atau lebih, sedangkan fakir ialah orang yang memiliki kurang dari separuh kebutuhannya (Qardawi, 2011: 514).

3. Amil Zakat

Amil zakat adalah semua pihak yang bertindak mengerjakan yang berkaitan dengan pengumpulan, penyimpanan, 
penjagaan, pencatatan dan penyaluran atau pendistribusian harta zakat. Mereka diangkat oleh pemerintah dan memperoleh izin darinya atau dipilih oleh instansi pemerintah yang berwenang atau oleh masyarakat Islam untuk memungut, membagikan serta tugas lain yang berhubungan dengan zakat.

Amil zakat merupakan orang yang bertugas mengelola zakat, maka seorang amil hendaknya memenuhi syarat-syarat sebagai berikut (Qardawi, 2011: 551):

a. Seorang amil sebaiknya seorang muslim, karena zakat itu urusan kaum muslimin, maka Islam menjadi syarat utama bagi segala urusan zakat.

b. Seorang amil harus seorang yang mukallaf, yaitu orang yang dewasa yang sehat akal fikirannya.

c. Seorang amil itu hendaknya jujur, karena ia telah diberi amanah dalam mengelola harta kaum muslimin.

d. Seorang amil harus memahami hukum-hukum zakat. Para ulama mensyaratkan petugas zakat itu faham terhadap hukum zakat, sebab apabila ia tidak mengetahui hukum maka ia tidak akan mampu melaksanakan pekerjaannya dan akan banyak berbuat kesalahan.

e. Amil harus mampu melaksanakan tugas yang telah diberikan.

f. Nabi melarang kerabatnya untuk menjadi amil zakat.

g. Amil zakat disyaratkan seorang lakilaki

h. Sebagian ulama mensyaratkan amil itu seorang yang merdeka dan bukan seorang hamba.

4. Muallaf

Muallaf adalah orang yang baru masuk Islam kurang dari satu tahun yang masih memerlukan bantuan dalam beradaptasi dengan kondisi baru mereka, meskipun tidak berupa pemberian nafkah, atau dengan mendirikan lembaga keilmuan dan sosial yang akan melindungi dan memantapkan hati mereka dalam memeluk Islam serta yang akan menciptakan lingkungan yang serasi dengan kehidupan baru mereka, baik moril maupun materil.

Kelompok muallaf terbagi kedalam beberapa golongan, yang muslim maupun bukan muslim (Qardawi, 2011 : 563):

a. Golongan yang diharapkan ke-Islaman kelompok serta keluarganya.

b. Golongan orang yang dikhawatirkan kelakuan jahatnya. Mereka termasuk kedalam mustahik zakat, dengan harapan dapat mencegah kejahatannya.

c. Golongan orang yang baru masuk Islam. Mereka perlu diberi santunan agar bertambah mantap keyakinannya terhadap Islam.

d. Pemimpin dan tokoh masyarakat yang telah memeluk Islam yang mempunyai sahabat-sahabat orang kafir.

e. Pemimpin dan tokoh kaum muslimin yang berpengaruh dikalangan kaumnya, akan tetapi imannya masih lemah.

f. Kaum muslimin yang bertempat tinggal di benteng-benteng dan daerah perbatasan dengan musuh.

g. Kaum muslimin yang membutuhkannya untuk mengurus zakat orang yang tidak mau mengeluarkan, kecuali dengan paksaan seperti dengan memeranginya.

5. Riqab/ Budak/ Hamba Sahaya Riqab adalah bentuk jamak dari raqabah. Dalam Al-Qur'an artinya budak 
belian laki-laki (abid) dan budak belian perempuan (amah). Al-Quran memberikan isyarah dengan kata kiasan dengan maksud bahwa perbudakan bagi manusia tidak ada bedanya seperti belenggu yang mengikatnya. Membebaskan budak belian berarti menghilangkan atau melepaskan belenggu yang mengikatnya.

Sayyid Rasyid Ridha mengemukakan dalam Tafsir Al-Manar yang dikutip oleh Yusuf Qardawi, bahwa bagian "fi riqab" boleh dipergunakan untuk membantu sesuatu bangsa yang ingin melepaskan dirinya dari penjajahan, apabila tidak ada sasaran membebaskan perorangan. Mazhab Imam Ahmad berpendapat bahwa zakat untuk golongan budak boleh diperuntukkan untuk menebus tawanan muslim yang ditangkap (Qardawi, 2011: 592).

6. Gharimin (Orang yang Berhutang)

Orang berhutang yang berhak menerima penyaluran zakat dalam golongan ini ialah:

a. Orang yang berutang untuk kepentingan pribadi yang tidak bisa dihindarkan, dengan syarat-syarat, hutang itu tidak untuk kemaksiatan, hutang itu melilit pelakunya, si pengutang tidak sanggup lagi melunasi hutangnya, hutang itu sudah jatuh tempo dan harus dilunasi.

b. Orang-orang yang berutang untuk kepentingan sosial, seperti berutang untuk mendamaikan antara pihak yang bertikai dengan memikul biaya diyat (denda kriminal) atau biaya barang-barang yang dirusak.

c. Orang yang berutang karena menjamin utang orang lain, dimana yang menjamin dan yang dijamin keduanya berada dalam kondisi kesulitan keuangan.

d. Orang yang berutang untuk membayar diyat karena pembunuhan tidak sengaja, apabila keluarga benar-benar tidak mampu membayar denda tersebut, begitu pula kas negara.

7. Fisabilillah

Fisabilillah dalam pengertian sempit adalah orang yang berjuang di jalan Allah, sedangkan dalam pengertian luas adalah melindungi dan memelihara agama serta meninggikan kalimat tauhid, seperti berperang, berdakwah, berusaha menerapkan hukum Islam, menolak fitnah-fitnah yang ditimbulkan oleh musuh-musuh Islam, membendung arus pemikiran-pemikiran yang bertentangan dengan Islam dan semua kegiatan yang bermuara pada kebaikan seperti mendirikan benteng, memakmurkan mesjid, termasuk mengurus mayat, para ilmuan yang melakukan tugas untuk kepentingan umat Islam, juga diberikan untuk pelaksanaan program atau kegiatan untuk mewujudkan kemaslahatan umum umat Islam, seperti benteng, mendirikan rumah sakit dan pemberian layanan kesehatan. (Nasution,1987: 179).

Dari tafsir Ibnu Atsir tentang kalimat sabilillah, terbagi menjadi dua, yaitu: (Atsir : 156)

- Arti asal kata ini menurut bahasa, adalah setiap amal perbuatan ikhlas yang dipergunakan untuk bertaqarrub kepada Allah SWT meliputi segala amal perbuatan sholeh, baik yang bersifat pribadi maupun bersifat kemasyarakatan.

- Arti yang biasa dipahami pada kata ini apabila bersifat mutlak adalah jihad, 
sehingga karena seringnya dipergunakan untuk itu, seolah-olah artinya khusus untuk jihad.

Adapun menurut pendapat ulamaulama fikih tentang fisabilillah adalah sebagai berikut:

a) Mazhab Hanafi

Al-Sarakhshi menyebutkan, dalam mazhab Hanafi ditemukan beberapa pengertian arti kata fisabilillah, yaitu sukarelawan yang terputus bekalnya. Yang dimaksud dengan yang terputus adalah mereka yang tidak sanggup bergabung dengan tentara Islam karena kefakiran mereka, dengan sebab rusaknya perbekalan/ kendaraan/hewan tunggangan atau yang lainnya. Maka dihalalkan bagi mereka zakat, walaupun mereka mampu berusaha karena jika mereka berusaha maka menyebabkan mereka tertinggal dari jihad. Sarakhshi menambahkan bahwa pengertian yang pertama dinisbahkan kepada Abu Yusuf, dan yang kedua pendapat Muhammad AlSyaibani (Al-Sarakhsi, 1993: 10).

Golongan Hanafi yang dikutip oleh Yusuf Qardawi juga sepakat bahwa zakat itu adalah merupakan hak seseorang, karena zakat yang dikeluarkan tidak boleh digunakan untuk mendirikan masjid, membangun jembatan-jembatan, memperbaiki jalan, tempat-tempat minum, membendung sungai (dam), haji, jihad ataupun yang tidak bersifat kepemilikan (Qardawi, 2011: 613)

b) Mazhab Maliki

Muhammad bin Abdul Hakam berkata: "Dikeluarkan dari zakat untuk membuat baju perang/besi, senjata dan alat perang lainnya yang dibutuhkan untuk mencegah serbuan musuh karena ini semua termasuk syarat berperang dan kesiapan perang. Nabi SAW pernah mengeluarkan dari zakat sebanyak seratus unta dalam peperangan Sahl bin Abi Hasma, untuk memadamkan api pemberontakan (Qardawi, 2011 : 613).

Menurut Al-Dasuqi dalam karyanya Hasyiyah al-Dasuqi, pejuang dengan lafaz "al-jihad" hanya diberi zakat bila memiliki persyaratan : muslim, laki-laki, baligh, dan berkemampuan untuk berjuang (Ahmad, 1996 : 105). Sementara pejuang non muslim, misalnya ahli zimmah, pejuang perempuan, pejuang anak-anak dan tidak ada kemampuan untuk berjuang tidak termasuk dalam kategori fisabilillah menurut mazhab ini.

Kesimpulan dari Mazhab Maliki tentang fisabilillah adalah Mereka sepakat bahwa fisabilillah itu berkaitan dengan perang, jihad dan yang semakna dengan itu seperti pos penjagaan. Mereka juga berpendapat bahwa zakat boleh diberikan kepada mujahid dan pengawal perbatasan walaupun keadaannya kaya. Jumhur Ulama Maliki juga memperbolehkan zakat untuk kepentingan jihad, seperti senjata, kuda, benteng-benteng, kapal-kapal perang dan sebagainya.

c) Mazhab Syafi'i

Al-Nawawi menyebutkan dalam alMajmu' bahwa yang dimaksud dengan fisabilillah adalah pejuang di medan perang: "Mereka adalah orang-orang yang berperang dengan sukarela sedang mereka tidak memperoleh hak ketenteraan muslim dari negara. Karena itu mereka tidak diberi zakat dari bagian orang yang berperang, sebab memperoleh rezeki dari harta rampasan perang". Senada dengan ini, Zainuddin Malibari dari kalangan Syafi iyyah dalam kitabnya Fath al-Mu in menyebutkan definisi fisabilillah yaitu: "Pejuang agama 
sukarelawan sekalipun kaya, maka pejuang diberi bagian sebagai nafkahnya, pakaiannya dan juga untuk keluarganya selama masa pergi dan pulang, demikian pula diberi biaya alat peperangan (AlMalibari:193) ". Mazhab Syafi i sejalan dengan Mazhab Maliki dalam mengkhususkan sasaran zakat pada fisabilillah, dan membolehkan memberi mujahid yang dapat menolongnya dalam berjihad, walaupun kaya, serta boleh menyerahkan zakat untuk memenuhi yang mutlak diperlukan, seperti senjata dan perlengkapan lainnya. Akan tetapi dalam hal ini Mazhab Syafi i berbeda pendapat dengan Mazhab Maliki yaitu mereka mensyaratkan pejuang sukarelawan itu tidak mendapat bagian atau gaji yang dianggarkan oleh negara.

d) Mazhab Hanbali

Pandangan Hanabilah terhadap fisabilillah banyak persamaan dengan yang dikemukakan Syafi iyah, tetapi mereka menambahkan bahwa cakupan yang dikehendaki dari pengertian fisabilillah lebih luas. Menurut mereka penjaga benteng pertahanan juga dinamakan bagian perang walaupun tidak ada penyerangan, juru rawat, tukang masak, dan lainnya yang berhubungan dengan peperangan (Qardawi, 2011 : 616). Dalam penggunaan dalil, Hanabilah menggunakan nash Al-Qur`an seperti pegangan Syafi iyyah.

Perbedaan lain antara dua mazhab itu adalah pada pelaksana haji. Namun, pandangan ini diperselisihkan mereka. Ibnu Qudamah mengatakan haji tidak termasuk dalam fisabilillah, karena haji seseorang yang miskin tidak memberi manfaat bagi umum. Apabila haji dilaksanakan dengan harta zakat, kegunaan hanya terbatas pada diri pelaku saja. Sedangkan fisabilillah dikehendaki manfaat kolektif (Qudamah : 692).

e) Pendapat Rasyid Ridha

Menurut Rasyid Ridha pengarang kitab tafsir Al-Manar, fisabilillah adalah kemaslahatan umum kaum muslimin, yang dengannya tegak urusan agama dan pemerintahan, dan bukan untuk kepentingan pribadi. Ibadah haji menjadi wajib bagi orang yang mampu dan tidak wajib bagi orang yang tidak mampu. Oleh karena itu ibadah haji tidak termasuk kemaslahatan agama yang besifat umum. Akan tetapi untuk kepentingan syiar ibadah haji dan kepentingan umat untuk melaksanakannya, seperti mengamankan jalan-jalan yang akan dilaluinya, memenuhi kebutuhan air dan makanan serta mengurus kesehatan jamaah, maka hal-hal tersebut itu boleh mengambil bagian dari fisabilillah (Qardawi,2011:623).

f) Pendapat Syeikh Mahmud Syaltut

Syeikh Mahmud Syaltut dalam bukunya Islam Aqidah dan Syari'ah dalam hal ini menyatakan, fisabilillah adalah seluruh kemaslahatan umum yang tidak dimiliki oleh seseorang dan yang tidak hanya dimanfaatkan oleh seseorang, kepemilikannya hanya milik Allah dan kemanfaatannya hanya untuk makhluk Allah.Yang paling utama adalah mempersiapkan perang dalam rangka menolak umat yang jahat, memelihara kemuliaan, seperti persiapan segala yang dibutuhkan untuk kemanusiaan, pembuatan rumah sakit tentara maupun rumah sakit umum, pembuatan jalan, pembuatan garis-garis batas dan yang lainnya yang dikenal dengan ahli perang dan ahli medan. Mencakup pula untuk mempersiapkan dai-dai muda yang kuat untuk menjelaskan keindahan dan 
ketinggian Islam, menerangkan hikmah Islam serta menyampaikan hukumhukumnya, menjelaskan kelemahan argumentasi musuh sehingga tertolaklah tipu daya mereka (Qardawi,2011: 624).

g) Pendapat Shadiq Hasan Khan

Fisabilillah adalah mempergunakan zakat bagi para intelektual muslim yang tegak berdiri mengurus kemaslahatan agama. Sesungguhnya bagi mereka ada hak harta dari Allah, baik miskin, kaya fakir dan sebagainya. Bahkan menyisihkan sebagian harta untuk kepentingan ini termasuk salah satu hal yang terbaik. Karena Ulama adalah pewaris para Nabi dan pembawa agama. Di pundak mereka terpikul kesucian Islam dan syariah Rasulullah pemimpin umat (Khan : 115).

h) Pendapat Yusuf Qardhawi

Fisabilillah menurut Yusuf Qardawi adalah sebagai berikut:

- Membangun pusat-pusat dakwah (alMarkaz Al-Islami) yang menunjang program dakwah Islam di wilayah minoritas, dan menyampaikan risalah Islam kepada non muslim di berbagai benua merupakan jihad fisabilillah.

- Membangun pusat-pusat dakwah (alMarkaz Al-Islami) di negeri Islam sendiri yang membimbing para pemuda Islam kepada ajaran Islam yang benar serta melindungi mereka dari pengaruh ateisme, kerancuan fikrah, penyelewengan akhlak serta menyiapkan mereka untuk menjadi pembela Islam dan melawan para musuh Islam adalah jihad fisabilillah.

- Menerbitkan tulisan tentang Islam untuk mengantisipasi tulisan yang menyerang Islam, atau menyebarkan tulisan yang bisa menjawab kebohongan para penipu dan keraguan yang disuntikkan musuh Islam, serta mengajarkan agama Islam kepada para pemeluknya adalah jihad fisabilillah.

- Membantu para du'at Islam yang menghadapi kekuatan yang memusuhi Islam dimana kekuatan itu dibantu oleh para thagut dan orang-orang murtad, adalah jihad fisabilillah.

- Termasuk di antaranya untuk biaya pendidikan sekolah Islam yang akan melahirkan para pembela Islam dan generasi Islam yang baik atau biaya pendidikan seorang calon kader dakwah/da i yang akan diprioritaskan hidupnya untuk berjuang di jalan Allah melalui ilmunya adalah jihad fisabilillah.

8. Ibnu Sabil

Ibnu Sabil menurut jumhur ulama adalah kiasan untuk musafir, yaitu orang yang melintas dari satu daerah ke daerah lain. Ibnu Zaid berpendapat, Ibnu Sabil adalah musafir, apakah ia kaya atau miskin, apabila mendapat musibah dalam bekalnya, atau hartanya sama sekali tidak ada, atau terkena musibah atas hartanya, atau ia sama sekali tidak memiliki apaapa, maka dalam keadaan demikian itu, hanya bersifat pasti (Qardawi, 2011 : 655).

Golongan ini diberi zakat dengan syarat-syarat :

a. Sedang dalam perjalanan di luar lingkungan negeri tempat tinggalnya. Jika masih dilingkungan negara tempat tinggalnya lalu ia dalam keadaan membutuhkan, maka ia dianggap sebagai fakir atau miskin.

b. Perjalanan tersebut tidak bertentangan dengan syariat Islam, sehingga pemberian zakat itu tidak 
menjadi bantuan untuk berbuat maksiat.

\section{Metodologi Penelitian}

Penelitian ini bertujuan untuk melihat lembaga pengelola zakat Indonesia dalam mendistribusikan zakat kepada fisabilillah dan melihat kesesuaian kriteria fisabilillah di lembaga pengelola zakat Indonesia dengan kriteria fisabilillah menurut syariat Islam.

Metode analisis data dalam penelitian ini menggunakan metode Analytic Hierarchy Process (AHP).Karena dalam menyelesaikan masalah metode AHP lebih tersturuktur, terorganisir dan fungsional dalam pengontrolan dan penurunan kedalam sistem dan peyelesaian. Dan metode AHP membantu dalam menentukan prioritas dari beberapa kriteria dengan melakukan analisis perbandingan berpasangan masing-masing kriteria.

Langkah-langkah yang harus dilakukan dalam menggunakan AHP untuk pemecahan suatu masalah adalah sebagai berikut: (1) Mendefinisikan masalah dan menentukan solusi (2) Menentukan prioritas elemen (3) Sintesis (4) Mengukur Konsistensi.

\section{HASIL DAN PEMBAHASAN}

\section{Analisis Kriteria Fisabilillah}

Dari empat mazhab ulama fikih, mazhab Hanafi yang memiliki makna yang paling sempit dalam mengartikan fisabilillah sebagai mustahik zakat, yaitu pejuang sukarelawan perang yang terputus bekalnya, jama'ah haji yang habis bekalnya, pencari ilmu atau orang berjuang dijalan kebajikan dengan syarat fakir dan membutuhkan. Sedangkan tiga mazhab yang lain (mazhab Maliki, Syafi'i dan Hanbali) saling melengkapi makna fisabilillah sebagai mustahik zakat dengan menambahkan peralatan perang dan semua kebutuhan perang lainnya sebagai yang berhak menerima zakat. Tetapi keempat mazhab tersebut memaknai fisabilillah hanya kepada segala sesuatu yang berhubungan dengan perang saja.

Pada saat ini, makna fisabilillah dalam pengertian sempit yaitu perang/jihad sudah tidak ada, sehingga penulis mengasumsikan makna perang/jihad yaitu dengan da'i. Pada masa sekarang ini, jihad fisabilillah secara fisik tidak terlalu besar, sementara tarbiyah dan pembinaan umat yang selama ini terbengkalai memerlukan dana yang besar. Oleh karena itu da'i/ustadz juga merupakan salah satu orang yang berjuang dengan menggunakan ilmu agama dan orang yang menyebarluaskan ilmu-ilmu yang terdapat didalam ajaran Islam. Sedangkan makna umum dari jihad adalah segala pengorbanan harta dan jiwa demi menegakkan kalimat Allah (Islam) atau membela kepentingan agama dan umat Islam.

Adapun kriteria-kriteria da'i/ustadz yang penulis asumsikan untuk mendapatkan dana zakat adalah:

1. Ustadz yang mengajarkan agama dan juga memiliki pekerja lainnya,

2. Ustadz yang hanya mengajarkan agama Islam

3. Ustadz yang kegiatannya hanya ceramah.

Tiga ulama mazhab (mazhab Maliki, mazhab Syafi'i dan mazhab Hanbali) mereka sepakat, dana zakat dapat digunakan untuk kebutuhan perang seperti senjata perang, kendaraan untuk perang, membangun benteng, parit dan 
lain-lain. Karena kriteria jihad diasumsikan menjadi da'i/ustadz maka untuk peralatan perang juga diasumsikan menjadi peralatan dakwah yang dapat membantu da'i/ustadz dalam menyebarkan agama Islam sehingga da'i/ustadz dapat dengan mudah menyampaikannya.

Adapun yang termasuk kedalam peralatan dakwah adalah Tempat untuk dakwah, Buku/kitab sebagai materi dakwah dan Media dakwah sebagai pengantar dakwah kepada masyarakat baik melalui media maupun langsung.

Adapun ringkasan dari penjelasan diatas dapat dilihat dalam skema berikut:

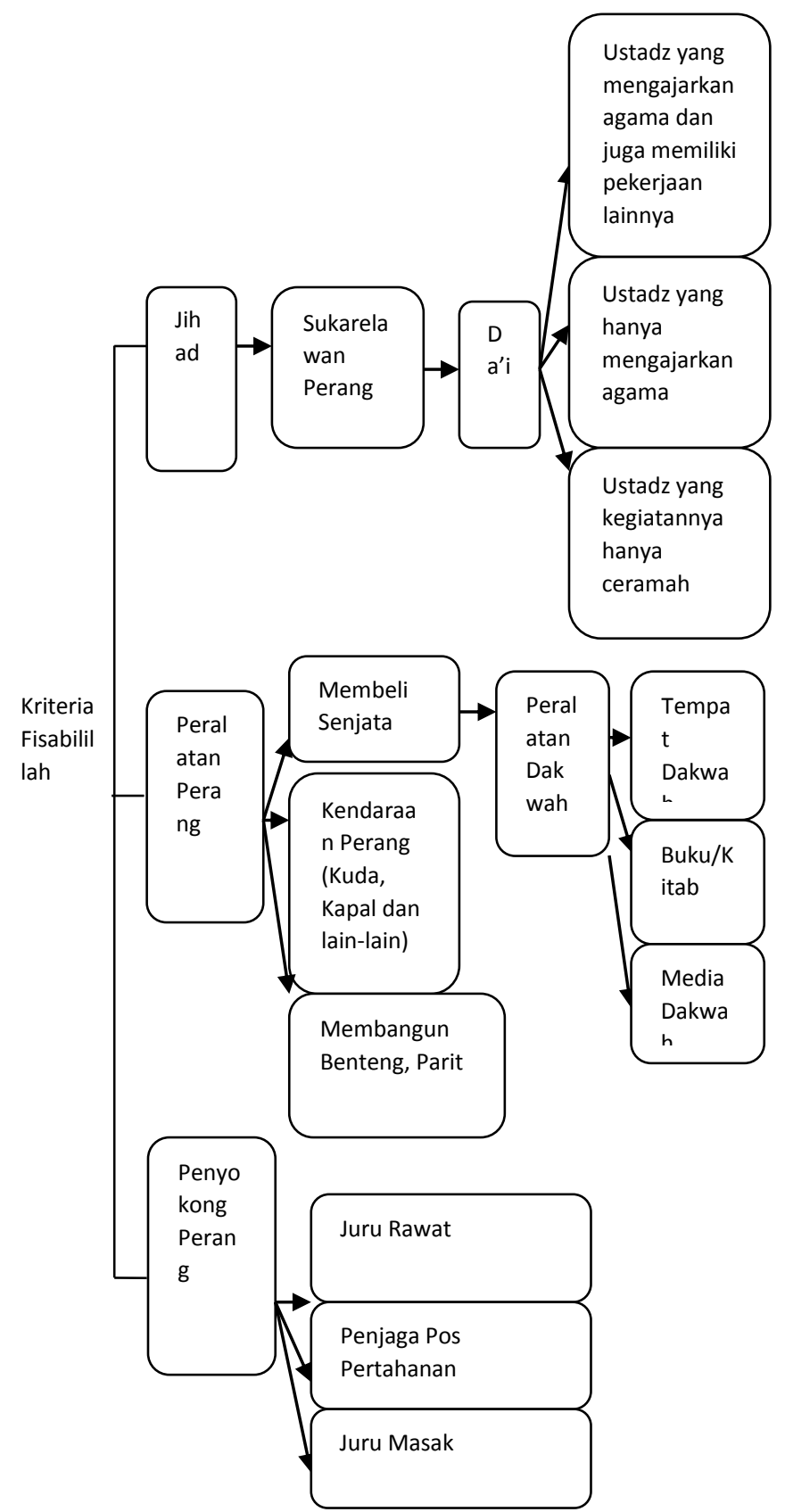

Sumber : Peneliti (2015)

Gambar 1.

Skema Kriteria Fisabilillah

Selain empat ulama mazhab, ulamaulama kontemporer juga berbeda pendapat mengenai makna fisabililillah sebagai sasaran penerima zakat. Adapun ulama-ulama kontemporer yang memiliki pandangan mengenai fisabilillah diantaranya adalah Rasyid Ridha, Syeikh 
Mahmud Syaltut, Shadiq Hasan Khan, Yusuf Qardawi dan Imamiah Ja'fari.

Menurut ulama kontemporer, makna fisabilillah dalam pengertian sempit yaitu perang/jihad sudah tidak ada, sehingga penulis juga mengasumsikan makna perang/jihad yaitu dengan perang dalam rangka menolak kaum yang jahat dan perang dengan lisan dengan kriteria orang yang menyebarkan ilmu dan hujjah yang bathil dan orang yang melakukan kejahatan kepada orang yang lemah, menjelaskan ilmu agama Islam kepada masyarakat serta ustadz yang kegiatannya hanya ceramah.

Adapun kriteria kemaslahatan umum diasumsikan zakat dapat diberikan untuk sekolah Islam, tempat pelatihan, majelis ta'lim dan organisasi Islam. Penulis mengasumsikan kepada golongan tersebut karena sekolah Islam, tempat pelatihan dan organisasi Islam merupakan tempat bagi masyarakat untuk memperdalam ilmu tentang Islam. Sedangkan untuk kriteria Dai/Intelektual Muslim penulis mengasumsikan zakat dapat diberikan untuk beasiswa karena dengan mendapatkan beasiswa mampu untuk mendapatkan ilmu agama dengan sempurna tanpa harus memikirkan biaya untuk hidupnya.

Setelah mengetahui pendapat kedua ulama yaitu ulama empat mazhab dan ulama kontemporer, maka peneliti menyimpulkan kriteria-kriteria fisabilillah berdasarkan pendapat ulama yang banyak disepakati terhadap perluasan makna fisabilillah sampai kepada kriteria fisabilillah yang sedikit disepakati oleh para ulama tersebut.
Adapun level kriteria fisabilillah berdasarkan kesepakatan ulama adalah sebagai berikut:

- Pada level 1, kriteria fisabilillah adalah jihad. Karena semua penjelasan dalam Al-Qur'an dan Hadits serta ulama fikih sepakat bahwa makna fisabilillah adalah jihad/perang. Yang termasuk kedalam kriteria jihad adalah jihad ke Palestina, Ustadz/Da'I yang kegiatannya hanya ceramah saja, Ustadz/Da'I mengajarkan agama dan memiliki usaha, Orang yang Menyebarkan ilmu dan hujjah yg bathil, Ustadz/Da'I yang Mengajarkan Islam saja dan Orang yg Melakukan Kejahatan Kepada yang Lemah.

- Pada level 2, kriteria fisabilillah adalah peralatan perang (dakwah). Pada kriteria peralatan perang, ulama mazhab Hanafi saja yang tidak sepakat terhadap dana zakat yang dialokasikan untuk peralatan perang. Adapun yang termasuk kedalam kriteria peralatan perang (dakwah) adalah tempat dakwah, buku/kitab dan media dakwah.

- Pada level 3, kriteria fisabilillah adalah beasiswa. Karena sebagaian ulama fikih sepakat bahwa zakat untuk golongan fisabilillah dapat diberikan untuk kepentingan menuntut ilmu. Adapun yang termasuk kedalam kriteria beasiswa adalah beasiswa SD, beasiswa SMP, beasiswa SMA dan beasiswa kuliah.

- Pada level 4, kriteria fisabilillah adalah untuk kemaslahatan umum. Pada kriteria kemaslahatan umum, ulama yang memberikan perluasan makna fisabilillah terhadap kriteria ini berpendapat bahwa kemaslahatan 
umum dapat membantu masyarakat untuk mendapatkan haknya terhadap kemaslahatan umum dan juga sepakat bahwa kemaslahatan untuk umum untuk kepentingan umat bersama dengan tujuan untuk mendekatkan diri kepada sang pencipta, yaitu Allah. Adapun yang termasuk kriteria dari kemaslahatan umum adalah mendirikan rumah sakit, membangun jembatan, membangun pusat dakwah Islam, membiayai da'i/intelektual muslim dan membangun lapangan udara. Semua kriteria itu dimaksudkan untuk lebih mendekatkan diri kepada Allah SWT.

- Pada level 5, kriteria fisabilillah adalah pusat dakwah Islam. Pada kriteria ini hanya beberapa ulama saja yang sepakat dana zakat diberikan untuk golongan ini. Adapun yang termasuk kedalam kriteria pusat dakwah Islam sekolah Islam, majelis ta'lim, tempat pelatihan dan organisasi Islam.

\section{Kriteria Fisabilillah Lembaga} Pengelola Zakat di Indonesia

Dari hasil wawancara di lembaga zakat Dompet Peduli Ummat Daarut Tauhiid Bandung, dana zakat yang dialokasikan untuk golongan fisabilillah hanya pada dua kriteria saja yaitu beasiswa bagi para penghafal Al-Qur'an yang berada di Baitul Qur'an Daarut Tauhiid dan beasiswa untuk mahasiswa. Adapun beasiswa diberikan kepada dua golongan tersebut dengan syarat bagi mereka yang ingin fokus menghafalkan Al-Qur'an namun tidak memiliki biaya (tidak mampu) dan bagi mereka yang memiliki prestasi dalam bidang keilmuan.

Pada lembaga DPU-DT, dana yang dialokasikan untuk golongan fisabilillah kurang lebih hanya $12 \%$ dari total dana zakat yang diterima. Menurut peneliti lembaga DPU-DT tidak terlalu memperhatikan bagi mustahik golongan fisabilillah, fokus mereka hanya pada mustahik golongan fakir dan miskin.

Menurut Siti Rofingah mahasiswa IAIN Walisongo Semarang tahun 2006 dengan judul "Analisis Pendapat Yusuf AlQardawi Tentang Konsep Fisabilillah Dalam Zakat". Hasil dari skripsi ini menjelaskan bahwa menurut Yusuf Qardawi, makna fisabilillah yaitu jihad dengan menegakkan agama Allah baik dengan senjata maupun non senjata. Menurut Qardawi, saat ini perang untuk menegakkan agama Allah bisa dilakukan dalam bentuk perang pena atau perang saraf. Menurut Qardawi bila berpegang pada pendapat yang sempit maka fungsi zakat menjadi kurang efektif, karena yang disebut perang pada saat ini bukan hanya dalam bentuk senjata tetapi juga dalam bentuk non senjata. Sebaliknya bila berpegang pada pendapat yang luas, maka makna zakat menjadi keluar dari asnaf yang delapan, sehingga distribusi zakat menjadi tidak jelas, dan asnaf yang ada dalam Al-Qur'an menjadi kehilangan hak menerima zakat akibat habisnya distribusi zakat yang diberikan pada setiap jalan yang mendekatkan diri pada Allah (Rofingah, 2006).

Skripsi yang disusun oleh Machmud Sa'roni mahasiswa IAIN Walisongo dengan judul "Redifinisi Fisabilillah Sebagai Mustahik Zakat, Relevansinya dengan Masa Sekarang". Hasil dari skripsi ini adalah bahwa fisabilillah baik dalam pengertian sempit dan pengertian luas memiliki tujuan yang sama yaitu mewujudkan keadilan dan kesejahteraan umat. Diantara kelompok fisabilillah 
disini adalah seseorang yang berperang dengan tujuan agar kalimah Allah tegak, mendirikan sekolah dengan tujuan membendung misi zending (kristenisasi), untuk menghadapi propaganda para kufar yang menyebarkan idiologinya lewat media konkrit visual, seperti media buku, majalah, dan visual seperti televisi, internet, dan handphone yang bertujuan memadamkan api Islam dan mencegah ruh Islam kepelosok dunia (Sa'roni, 2004).

Skripsi yang disusun oleh Mar'atus Sholikhah mahasiswa IAIN Walisongo tahun 2006 dengan judul "Hukum Zakat Yang Di Tasharufkan Pada Masjid (Hasil Bahtsul Masa'il NU Wilayah Jawa Timur Pada Tanggal 26-27 Agustus 1981). Hasil dari skripsi ini bahwa penasyarufan zakat untuk masjid adalah tidak diperbolehkan, karena masjid bukan salah satu dari golongan yang berhak menerima zakat. Menurut kitab Bughyatul Mustarsyidin dan Mizan Kubra bahwa zakat tidak boleh dialokasikan kepada selain penerima zakat, seperti keperluan mengkafani mayat, membangun jembatan, memugarkan masjid dan hal-hal lain walaupun bersifat amal kebaikan. Dan makna fisabilillah menurut hasil bahtsul masa'il diniyah NU wilayah Jawa Timur adalah jihad atau perang membela kebenaran agama Allah. Pengalokasian zakat untuk masjid adalah tidak boleh, karena masjid bukanlah termasuk kategori fisabilillah (Sholikhah, 2006).

Fisabilillah dalam pengertian sempit adalah orang yang berjuang dijalan Allah, sedangkan dalam pengertian luas adalah segala amal perbuatan yang mendekatkan diri kepada Allah. Banyak ulama fikih yang memperluas makna fisabilillah sehingga penulis ingin mengetahui kriteria-kriteria fisabilillah di lembaga pengelola zakat Indonesia.

Adapun hasil wawancara peneliti dengan lembaga Rumah Zakat, dana zakat untuk golongan fisabilillah kurang lebih hanya $10 \%$ dari dana zakat yang diterima dan dana zakat tersebut dialokasikan kepada Da'i, panitia pada peringatan hari besar Islam, dan lembaga dakwah. Menurut peneliti, Rumah Zakat memperluas makna fisabilillah dengan memberikan dana zakat kepada tiga golongan. Rumah zakat memperluas makna jihad dengan da'I dan lembaga dakwah, sama seperti yang peneliti asumsikan. Pada zaman ini perang dengan mengangkat senjata itu sudah tidak ada sehingga mengasumsikan jihad dengan jihad menggunakan ilmu, agar menghindari dari kerancuan fikrah. Sedangkan hasil dari wawancara pada lembaga zakat Dompet Dhuafa, dana zakat yang dialokasikan untuk golongan fisabilillah adalah beasiswa bagi pelajar, bantuan untuk Negara yang sedang perang.

\section{Analytic Hierarki Prosses (AHP) Kriteria Fisabilillah Lembaga Pengelola Zakat di Indonesia}

Dalam menganalisis kriteria fisabilillah di lembaga pengelola zakat Indonesia dengan metode AHP, ada beberapa langkah-langkah yang harus diikuti. Adapun langkah-langkah dalam menganalisis kriteria fisabilillah dengan metode AHP adalah sebagai berikut (Manurung, 2010):

- Penyusunan Hirarki (Decomposition)

Sistem yang kompleks bisa dipahami dengan memecahkannya menjadi elemen-elemen yang lebih kecil dan mudah dipahami. Adapun 
penyusunan hirarki dalam penelitian ini adalah sebagai berikut:

a. Fisabilillah dengan kriteria jihad

Adapun kriteria-kriteria jihad dalam pengertian fisabilillah adalah sebagai berikut:

- Jihad ke Palestina

- Ustadz/da'I yang kegiatannya hanya ceramah

- Ustadz/da'I mengajarkan agama dan memiliki usaha

- Melawan orang yang menyebarkan ilmu dan hujjah yang bathil

- Ustadz/da'I yang mengajarkan Islam saja

- Melawan orang yang melakukan kejahatan kepada yang lemah

b. Fisabilillah dengan kriteria peralatan dakwah

Adapun kriteria-kriteria peralatan dakwah adalah sebagai berikut:

- Tempat dakwah

- Buku/kitab

- Media dakwah

c. Fisabilillah dengan kriteria beasiswa.

Adapun yang termasuk kedalam kriteria beasiswa adalah sebagai berikut:

- Beasiswa SD,

- Beasiswa SMP,

- beasiswa SMA

- Beasiswa Kuliah.

d. Fisabilillah dengan kriteria kemaslahatan umum.

Adapun yang termasuk kriteria dari kemaslahatan umum adalah sebagai berikut:

- Mendirikan Rumah Sakit,

- Membangun Jembatan,

- Membangun Pusat Dakwah Islam,

- Membiayai Da'i/Intelektual Muslim

- membangun lapangan udara. e. Fisabilillah dengan kriteria pusat dakwah Islam.

Adapun yang termasuk kedalam kriteria pusat dakwah Islam adalah sebagai berikut:

- Sekolah Islam,

- Majelis Ta'lim,

- Tempat Pelatihan

- Organisasi Islam.

- Kriteria dan Alternatif Dilakukan dengan Perbandingan Berpasangan.

Menurut Saaty (1988), untuk berbagai persoalan, skala 1 sampai 9 adalah skala terbaik untuk mengekspresikan pendapat. Nilai dan definisi pendapat kualitatif dari skala perbandingan Saaty dapat diukur menggunakan tabel analisis seperti Tabel dibawah ini.

Tabel 2.

Skala Penilaian Perbandingan Pasangan

\begin{tabular}{|l|l|}
\hline $\begin{array}{c}\text { Intensitas } \\
\text { Kepentinga } \\
\text { n }\end{array}$ & \multicolumn{2}{|c|}{ Keterangan } \\
\hline 1 & $\begin{array}{l}\text { Kedua elemen sama } \\
\text { pentingnya }\end{array}$ \\
\hline 3 & $\begin{array}{l}\text { Elemen yang satu sedikit } \\
\text { lebih penting daripada } \\
\text { elemen yang lainnya }\end{array}$ \\
\hline 5 & $\begin{array}{l}\text { Elemen yang satu lebih } \\
\text { penting daripada yang } \\
\text { lainnya lebih }\end{array}$ \\
\hline 7 & $\begin{array}{l}\text { Satu elemen jelas lebaripada } \\
\text { mutlak penting daripan } \\
\text { elemen lainnya }\end{array}$ \\
\hline 9 & $\begin{array}{l}\text { Satu elemen mutlak penting } \\
\text { daripada elemen lainnya }\end{array}$ \\
\hline $2,4,6,8$ & $\begin{array}{l}\text { Nilai-nilai antara dua nilai } \\
\text { pertimbangan-pertimbangan } \\
\text { yang berdekatan }\end{array}$ \\
\hline
\end{tabular}

Sumber: Pangeran Manurung, 2010 
- Synthesis of Prioritas (Menentukan Prioritas).

Prioritas ini ditentukan berdasarkan pandangan para pakar dan pihak-pihak yang berkepentingan terhadap pengambilan keputusan, baik secara langsung (diskusi) maupun secara tidak langsung (kuisioner).

- Mengukur Konsistensi

Rumus mengukur indeks konsistensi (Consistency Index):

$\mathrm{CI}=(\lambda \max -\mathrm{n}) / \mathrm{n}$

Dimana $\mathrm{n}=$ banyaknya elemen.

- Menghitung Rasio Konsistensi/ Consistency Ratio (CR)

Rumus mengukur CR adalah:

$\mathrm{CR}=\mathrm{CI} / \mathrm{RC}$

Dimana CR = Consistency Ratio

$\mathrm{CI}=$ Consistency Index

IR = Indeks Random Consistency

Jika nilainya CR lebih dari 10\%, maka penilaian data judgment harus diperbaiki. Namun jika Rasio Konsistensi (CI/CR) kurang atau sama dengan 0,1, maka hasil perhitungan bisa dinyatakan benar (Kusrini, 2007).

Tabel 3.

Ratio index

\begin{tabular}{|l|l|l|l|l|l|l|l|l|}
\hline $\begin{array}{l}\text { Orde } \\
\text { Matrik } \\
\text { s }\end{array}$ & 1 & 2 & 3 & 4 & 5 & 6 & 7 & 8 \\
\hline RI & $\begin{array}{l}0, \\
00\end{array}$ & $\begin{array}{l}0, \\
00\end{array}$ & $\begin{array}{l}0, \\
58\end{array}$ & $\begin{array}{l}0, \\
90\end{array}$ & $\begin{array}{l}1, \\
12\end{array}$ & $\begin{array}{l}1, \\
24\end{array}$ & $\begin{array}{l}1, \\
32\end{array}$ & $\begin{array}{l}1,4 \\
1\end{array}$ \\
\hline
\end{tabular}

Adapun hasil dari analisis peneliti dengan menggunakan metode AHP pada lembaga pengelola zakat Dompet Peduli Ummat Daarut Tauhiid (DPU-DT) adalah sebagai berikut:

- Fisabilillah dengan kriteria jihad

Pada lembaga pengelola zakat DPUDT, fisabilillah dengan kriteria jihad memiliki tingkat kepentingan yang berbeda. Fisabilillah dengan kriteria jihad berdasarkan hasil perhitungan rasio konsistensi didapati nilai CR yaitu 0,34 > 0,10 berarti matriks tersebut tidak konsisten. Maka dilanjutkan kembali dengan perhitungan vektor ulang dan analisis kembali sehingga menghasilkan matriks perbandingan berpasangan baru.

Pada lembaga DPU - DT fisabilillah dengan kriteria jihad lebih banyak disalurkan kepada melawan orang yang menyebarkan ilmu dan hujjah yang bathil yaitu 32\% dan melawan orang yang melakukan kejahatan kepada yang lemah yaitu $22,8 \%$. Sedangkan dana zakat yang disalurkan lebih sedikit dengan kriteria jihad yaitu ustadz/da'I mengajarkan agama dan memiliki usaha yaitu 3\%

- Fisabilillah dengan Kriteria Peralatan Dakwah

Fisabilillah dengan kriteria peralatan dakwah berdasarkan hasil perhitungan rasio konsistensi didapati nilai CR yaitu 0,15>0,10 berarti matriks tersebut tidak konsisten. Maka dilanjutkan kembali dengan perhitungan vektor ulang dan analisis kembali sehingga menghasilkan matriks perbandingan berpasangan baru.

Pada kriteria peralatan dakwah DPU - DT lebih banyak disalurkan kepada media dakwah yaitu $59,2 \%$ dan yang paling sedikit disalurkan kepada tempat dakwah yaitu 7,3\%

- Fisabilillah Dengan Kriteria Beasiswa

Fisabilillah dengan kriteria Beasiswa berdasarkan hasil perhitungan rasio konsistensi didapati nilai CR yaitu 0,25> 0,10 berarti matriks tersebut tidak konsisten. Maka dilanjutkan kembali dengan perhitungan vektor ulang dan analisis kembali sehingga menghasilkan matriks perbandingan berpasangan baru. 
Pada kriteria beasiswa DPU - DT lebih banyak disalurkan untuk beasiswa kuliah yaitu 52,5\% dan lebih sedikit diberikan kepada Beasiswa SD yaitu 4,3\%

- Fisabilillah dengan kriteria kemaslahatan umum

Fisabilillah dengan kriteria kemaslahatan umum Berdasarkan hasil perhitungan rasio konsistensi didapati nilai CR yaitu 0,30>0,10 berarti matriks tersebut tidak konsisten. Maka dilanjutkan kembali dengan perhitungan vektor ulang dan analisis kembali sehingga menghasilkan matriks perbandingan berpasangan baru.

Pada kriteria kemaslahatan umum DPU - DT lebih banyak menyalurkan dana zakat untuk membiayai dai yaitu $47,9 \%$ dan lebih sedikit disalurkan untuk membangun jembatan yaitu 7\%

- Fisabilillah dengan Kriteria pusat dakwah Islam

Fisabilillah dengan kriteria pusat dakwah Islam Berdasarkan hasil perhitungan rasio konsistensi didapati nilai CR yaitu 0,004 < 0,10 berarti matriks tersebut konsisten. Setelah matriks konsisten maka dapat dilanjutkan ke proses perankingan.

Pada kriteria pusat dakwah Islam DPU -DT lebih banyak menyalurkan dana kepada Sekolah Islam yaitu 59,4\% dan lebih sedikit disalurkan kepada tempat pelatihan $6,5 \%$.

Adapun hasil dari analisis peneliti dengan menggunakan metode AHP pada lembaga pengelola zakat Rumah Zakat adalah sebagai berikut:

- Fisabilillah dengan kriteria jihad

Pada lembaga pengelola zakat Rumah Zakat, fisabilillah dengan kriteria jihad memiliki kepentingan yang sama. Maksudnya setiap kriteria yang terdapat dalam jihad memiliki nilai yang sama. Jadi pandangan pengelola zakat terhadap kriteria-kriteria yang telah peneliti simpulkan proporsi untuk dana zakat yang dialokasikan sama besar.

- Fisabilillah dengan kriteria peralatan dakwah.

Begitu juga dalam kriteria peralatan dakwah. Rumah Zakat memiliki pandangan bahwa kriteria-kriteria peralatan dakwah sama pentingnya, tidak ada yang lebih dominan atau yang lebih penting.

Begitu pula dengan kriteria beasiswa, kriteria kemaslahatan umum dan kriteria pusat dakwah Islam, Rumah Zakat tidak memiliki kriteria yang lebih penting atau dominan sehingga nilai-nilai antar kriteria tersebut sama besar.

Berdasarkan hasil perhitungan rasio konsistensi didapati nilai CR yaitu 0,21 > 0,10 berarti matriks tersebut tidak konsisten. Maka dilanjutkan kembali dengan perhitungan vektor ulang dan analisis kembali sehingga menghasilkan matriks perbandingan berpasangan baru.

Fisabilillah dengan kriteria beasiswa. Berdasarkan hasil perhitungan rasio konsistensi didapati nilai CR yaitu $0,53>0,10$ berarti matriks tersebut tidak konsisten. Maka dilanjutkan kembali dengan perhitungan vektor ulang dan analisis kembali sehingga menghasilkan matriks perbandingan berpasangan baru.

Fisabilillah dengan kriteria kemaslahatan umum. Berdasarkan hasil perhitungan rasio konsistensi didapati nilai CR yaitu 0,30>0,10 berarti matriks tersebut tidak konsisten. Maka dilanjutkan kembali dengan perhitungan vektor ulang dan analisis kembali sehingga menghasilkan matriks perbandingan berpasangan baru. Jadi, 
Sistem Pendukung Keputusan ini membantu dalam penentuan keputusan bagi pihak pimpinan dalam perencanaan strategis, perencanaan strategis melalui inputan penilaian faktor, faktor baik internal maupun external yang juga didasarkan atas keterkaitan dengan visi, misi, dan nilai yang kemudian diperoleh rankingnya. Melalui ranking ini instansi melakukan strategi atas ranking yang utama berdasarkan skala prioritas tersebut guna mendukung kinerja instansi tersebut.

\section{KESIMPULAN DAN IMPLIKASI}

Kriteria fisabilillah yang penulis simpulkan dari beberapa sumber adalah orang yang berjuang dijalan Allah, untuk perlengkapan perang, untuk beasiswa, untuk kemaslahatan umum dan untuk pusat dakwah Islam. Adapun pada tiga lembaga pengelola zakat Indonesia yang mendefinisikan fisabilillah sebagai mustahik zakat adalah untuk para dai yang menyebarluaskan agama Islam, memberikan beasiswa baik untuk tingkat SD, SMP, SMA dan Kuliah. Pada tiga lembaga pengelola zakat Indonesia, untuk kriteria-kriteria mustahik golongan fisabilillah sudah sesuai dengan kriteria menurut syariat Islam.

Saran untuk Lembaga pengelola zakat Indonesia harus memiliki kriteria khusus untuk golongan fisabilillah sehingga kemungkinan akan terjadinya salah sasaran tidak akan terjadi. Badan Amil Zakat Nasional sebagai regulator harus mempunyai pedoman khusus untuk setiap kriteria mustahik, sehingga lembaga-lembaga zakat yang berada di Indnesia tidak akan keliru dalam mendistribusikan dana zakat. Lembaga pengelola zakat Indonesia harus melakukan transparansi dalam mendistribusikan zakatnya kepada masyarakat sehingga masyarakat tidak keliru.

\section{DAFTAR PUSTAKA}

Ahmad, Muhammad. 1996. Hasyiah alDasuqi. Jilid III. Beirut: Dar al-Fikr.

Al- Malibari, Zain Al Din. Fath al-Muin. Juz II. Indonesiaa: Toha Putra Semarang Al-Sarakhshi, Syam al-Din. 1993. AlMabsuth. Juz III. Beirut: Dar al-Fikr. Al-Utsaimin, Syaikh Muhammad Shalih. 2012. Enseklopedi Zakat. Pustaka As-Sunnah.

An-Nabahi, Taqyuddin. 1996. Membangun Sistem Ekonomi Alternatif; Perspektif Islam. Surabaya: Risalah Gusti.

Atsir, Ibnu. 2011. An-Nihayah Fi Gharib Al-Hadits, Beirut: Darul Kutub.

Dahlan, Abdul Azis. 2001. Enseklopedi Hukum Islam. Jakarta: Ichtiar Baru Van Hoever.

Mukhlisin. 2009. "Pendistribusian Dana Zakat Untuk Pemberdayaan ekonomi masyarakat pada Badan Amil Zakat Daerah (BAZDA) kab. Karawang". Skripsi. Jurusan Manajemen Dakwah dan Komunikasi. Universitas Islam Negeri Syarif Hidayatullah.

Nasution, Lahmuddin. 1987. Fiqh I. Jakarta: Logos Wacana Ilmu.

Qardawi, Yusuf. 2011. Hukum Zakat. Jakarta: Litera AntarNusa.

Qudamah, Ibnu. 1997. Al-Mughni. Juz I Mekkah Mukarramah. Dar al-Baz.

Rofingah, Siti. 2006. "Analisis Pendapat Yusuf Qardhawi tentang konsep Fisabillah dalam zakat". Skripsi. Program studi muamalah. Fakultas Syariah. IAIN Walisongo. Semarang.

Sa'roni, Machmud. 2004. "Redifinisi Fisabillah sebagai mustahik zakat, 
relevansinya dengan masa sekarang". Skripsi. Program studi AlAhwal Al-Syakhsiyah. Fakultas Syariah. IAIN Walisongo. Semarang. Sholikhah, Mar'atus. 2009. "Hukum Zakat Yang Di Tasharufkan Pada Masjid
(Hasil Bahtsul Masail NU Wilayah Jawa Timur Pada Tanggal 26 - 27 Agustus 1981)". Skripsi. Jurusan AlAhwal Al-Syakhsiyah. Fakultas Syariah. IAIN Walisongo. Semarang. 